\title{
FIFTY YEARS OF NATURE
}

By KERRY WOOD, Red Deer, Alta.

The late Dr. Henry George, physician in attendance at the death of the famous Chief Crowfoot, also is respectfully remembered as the organizer of The Alberta Natural History Society. Dr. George started the Society fifty years ago. He had a nature museum as a sideline to his medical practise at Innisfail, and the Society was really an off-shoot of the museum. But it wasn't just another small town club, because Dr. George was a man of amazing organizing ability and soon made the list of members read like an Alberta honor roll. The Hon. G. H. V. Bulyea, Lieutenant-Governor of Alberta during 1906, gladly paid his $\$ 1$ membership in the Society; so did the Hon. Frank Oliver, pioneer newspaperman of Edmonton, and Colonel James Walker of Calgary came to the small town of Innisfail especially to see Dr. George's museum.

\section{A branch of the Natural History} Society was organized at Red Deer during 1906, with Dr. George as the principal speaker. When the good medico moved from Innisfail to Red Deer a year later, the headquarters of the Society automatically became Red Deer and branches were formed at Edmonton, Calgary, Camrose, Medicine Hat, and Lethbridge. Somehow, Innisfail seems to have dropped off the Society's list about this time, though many Innisfail naturalists travelled the twenty miles to Red Deer to attend the annual meetings and banquets. There were marvelous banquets, too, featuring roast haunch of venison, boiled pickled tongue, American chicken with celery, $\mathrm{Ma}$ cedonian fruit jellies and prune pie, the final dessert listed being the prosaic tapioca pudding. This was the
1909 banquet, and the toast list had eighteen names on it!

Yet it wasn't only a social club. The naturalists discussed, even earlier than the 1906 organization meeting at Red Deer, the possibility of having the strikingly beautiful Red Deer Canyon created a provincial park. They worked on this worthy project throughout the years, but never succeeded with that venture. However, they did persuade the Dominion Government to create a Bird Sanctuary at Gaetz Lakes near Red Deer in 1922, and the beautiful, tree-surrounded lake region continues as a wildlife park to this day.

The pioneer nature club had the official blessing of the Department of Agriculture. Indeed government agriculturists often applied to the Society for scientific information about farm pests during the days before the department employed its own experts. Under the urging of the Minister of Agriculture, the Provincial Government used to give The Alberta Natural History Society an annual grant of $\$ 100$. The money was used to publish scientific booklets. First, a complete catalogue of the Dragonflies of Alberta, by F. C. Whitehouse, was released in March 1918. A larger and very valuable Check List of Moths and Butterflies of Alberta, by Kenneth Bowman, was published during 1919, and an Annotated List of the Coleoptera or Beetles of Alberta, by F. S. Carr, appeared a year later. The booklets are still in demand among entomologists in all parts of North America.

But you mustn't think that it was a stuffy, Latin-spouting gathering of highbrow experts. The monthly 
meetings were first held in the informal atmosphere of a book and fishing tackle store owned by John MacVicar, and the programs varied amazingly. One night, the versatile Dr. George led a discussion on the beneficial and harmful habits of Crows; another time his charming wife displayed her hundreds of colored paintings of Alberta flowers. Then Mr. C. H. Snell, a pioneer surveyor and one of the charter members of the Red Deer Society, came back from helping survey a base line west of Lake Athabaska and gave the members a fascinating account of the nature of that region - which included him inadvertently eating a rare Whooping Crane back in 1916! Mr. Snell, who still makes his home at Red Deer and is still a valued member of the Society, repeated the lecture on Lake Athabaska only a few months ago.

Sometimes the meetings took the form of a nature outing. The members visited the Tamarack Swamp three miles from Red Deer, and there found a great variety of rare flowers and insects. The Canyon was another favorite location for outings, to Christmas Island where members could use field glasses and watch the spectacular ariel hunts of the Peregrine Falcons; to the popular resort of Sylvan Lake, where the late Mrs. W. A. Cassells, beloved "bird-woman" of Red Deer, would lead an expedition to spy on a pair of Golden Eagles or to scout the hollow trees along the lake front where the first colonies of Purple Martins to settle in Central Alberta had their nests. Miss Mina Cole, the present botany expert of the Red Deer club, occasionally led an outdoor expedition and on several occasions the members gathered over 60 different plants on a single outing.

Today, the Natural History Society still thrives at Red Deer, a vigorous club that specializes in conservation measures. It gave away 3000 leaflets on bird-box buildings to the school children of Central Alberta during recent years. It defended and saved the beaver living within the Red Deer city limits on Waskasoo Creek. 300 farmers sought the Society's help in protecting deer in a farm belt, when the game department opened the area for hunting a few years ago. And the members act as Custodians of the Gaetz Lake Park, a 230 acre wildlife preserve near the city.

Fifty years of Nature Study, started by Dr. Henry George as a sideline to a private museum of nature oddities.

\section{A DATE WITH NATURE \\ (Continued from Page 1)}

meadow met, flourished stands of Grass of Parnassus. Here too, were the green spikes of Bog Orchids and an occasional clump of tall, hollowstemmed Cow Parsnip. Here and there, like a scattering of bright jewels, were small, orange-red mushrooms. These vividly-hued plants, Cone-shaped Hygrophorus, are edible, but Kathryn and I dislike their slimy characteristics that persist even after cooking.

The open hillsides were emblazened with the white, spicy, heads of Yarrow, rose flowers of Indian Paint Brush, tousled crests of drying Everlastings, and the purples of Peavine and Giant Hyssop.

At the head of an old, grassed-in trail, a blaze of lilies posed in regal splendor. One slender stalk boasted four glowing blossoms. I stiffled my urge to gather a large bouquet of these easily-killed plants and picked only. a token offering from a few single-blossomed stragglers.

Now and then, I lingered to pick strawberries, rich, glossy fruit, with unsurpassed flavor, that puts even their cultivated cousin to shame.

It was with a feeling of reluctance that I neared home. I wished that the hike could have lasted longer. One feels a serenity, a peace of mind when on intimate terms with nature, that nothing of man can ever quite match. 